\title{
A arte e pedagogia antirracista: Estratégias de efetivação da lei 10.639/12.
}

\section{Helen Santos Aguiar* Profa Dra Ana Elisa Spaolonzi Queiroz Assis}

\section{Resumo}

Essa pesquisa estuda algumas considerações das educadoras Ana Mae Barbosa, Nilma Lino Gomes e Bell Hooks de forma a unir o ensino da arte com as práticas antirracistas e a educação revolucionária na escola. Aproveitando a frequência com que algumas instituições de artes abordaram o universo poético negro no ano de 2018, parte-se dos materiais de apoio pedagógico que estas fizeram.

\section{Palavras-chave:}

Arte, educação, antirracista

\section{Introdução}

Essa iniciação científica avalia a importância do ensino de arte aliado a uma pedagogia revolucionária e anti racista. Estudando os escritos de Ana Mae Barbosa e suas reflexões sobre a história do ensino da arte e a formulação do que a escritora chama de abordagem triangular método que engloba o fazer artístico, a história da arte e a apreciação - a pesquisa direciona as possíveis práticas de implementação da lei 10.639/12 de forma a unir as práticas antirracistas com um ensino de arte qualificado, faz-se necessário então, entender os processos educacionais a partir da perspectiva de pedagogas e teóricas negras como Nilma Lino Gomes e Bell Hooks. As práticas de educação libertadora e a positivação da diferença racial que Bell Hooks aborda em Ensinando a transgredir e Olhares negros: raça e representação se unem com as considerações de Nilma Lino Gomes sobre o corpo do indivíduo negro e como suas marcas identitárias refletem na construção de sua imagem no ambiente escolar. Ressaltando a importância de possuir um material visual que possibilite o contato entre aluno e obra, aproveito os materiais pedagógicos que algumas instituições de arte elaboraram e distribuíram gratuitamente durante as exposições que, de alguma forma valorizaram a cultura negra e pensaram o negro como artista e não como objeto artístico, tais publicações abrem espaço para criar estratégias para as práticas antirracistas na arte educação.

\section{Resultados e Discussão}

Os materiais pedagógicos recolhidos e estudados trazem leituras recomendadas aos professores e sugestões de atividades que podem ser complementadas pelo professor. Algumas publicações como os cadernos de ensino da ocupação do llê Aiyê trazem uma perspectiva de ensino que o bloco desenvolve para a própria comunidade, inserindo conteúdos sobre a cultura negra e africana durante o ano todo. Para além dos cardernos, os materiais selecionados para a pesquisa propõem atividades que estão de acordo ou se aproximam da abordagem triangular envolvendo seus três aspectos com as reproduções das obras, as atividades práticas e os textos explicativos.

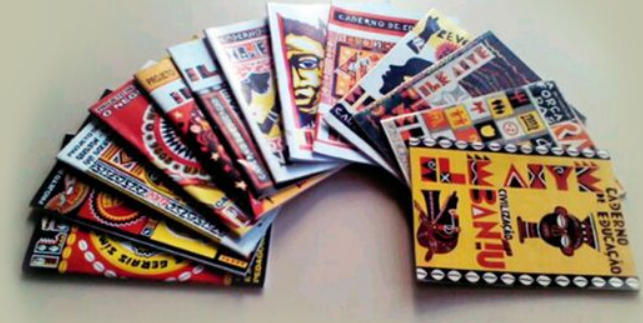

Fig.1 Cadernos de ensino do bloco afro llê Aiyê.

\section{Conclusões}

O período de pesquisa foi complementado por algumas ações educativas em instituições que realizam exposições temporárias e convidam escolas e ONGs para uma visita agendada. Observando a organização dessas ações educativas e o tempo destinado a elas chega-se à conclusão de que, mesmo uma exposição com temas libertadores que valorizem a presença negra, não configura uma prática eficiente dado ao curto prazo da ação, dessa forma a necessidade de pensar uma educação libertadora deve usar tais espaços e materiais como ferramentas que complementam a construção do pensamento antirracista e não como ação isolada que pode ou não provocar uma reflexão.

\section{Agradecimentos}

Essa pesquisa se concretizou graças ao fomento da Pibic e CNPq e à orientação da professora Dra Ana Elisa Spaolonzi Queiroz de Assis.

BARBOSA, Ana Mae Tavares Bastos. A imagem no ensino da arte: anos 1980 e novos tempos. 7. ed. São Paulo, SP: Perspectiva, 2009.

HOOKS, Bell. Ensinando a transgredir: a educação como prática da liberdade. Tradução de Marcelo Brandão Cipolla. 2. ed. São Paulo, SP: WMF Martins Fontes, 2017

GOMES, Nilma Lino. Trajetórias escolares, corpo negro e cabelo crespo: reprodução de estereótipos ou ressignificação cultural?. Rev. Bras. Educ. no.21, p.40-51, Dez 2002.

HOOKS, Bell. Olhares negros: raça e representação. Tradução de Stephanie Borges. 1 ed. São Paulo, SP: Editora Elefante, Fev 2019. 